\title{
Improvement of The Ability of Creative Thinking Mathematically Using Geogebra Assisted Think- Talk-Write Model
}

\author{
$1^{\text {st }}$ Machdalena \\ Mathematics Education Department \\ Universitas Pendidikan Indonesia \\ Bandung, Indonesia \\ siregarmachdalena970@student.upi.edu
}

\author{
$2^{\text {nd }}$ Sufyani Prabawanto \\ Mathematics Education Department \\ Universitas Pendidikan Indonesia \\ Bandung, Indonesia \\ sufyani_prabawanto@yahoo.com
}

\author{
$3^{\text {th }} \mathrm{Al}$ Jupri \\ Mathematics Education Department \\ Universitas Pendidikan Indonesia \\ Bandung, Indonesia \\ aljupri@upi.edu
}

\begin{abstract}
Mathematical creative thinking skills of Indonesian students are still not satisfactory, which is seen when students do the problem of reasoning in solving nonroutine problems. One of the alternative solution to overcome the problem is through the implementation of GeoGebra assisted Think-Talk-Write model. This type of research is literature review, so the method used is to summarize and anlyze the relevant research results that have been done. The Think-Talk-Write model refers to cooperative learning.
\end{abstract}

Keywords-Think-Talk-Write, GeoGebra, Creative Thinking, Cooperative Learning

\section{INTRODUCTION}

Mathematics is one of the basic sciences and contributes enormously in the progress of the nation. The importance of learning mathematics cannot be separated from its role in various aspects of life. In addition, by studying mathematics one accustomed to thinking systematically, scientifically, using logic, critical, and can increase the power of creativity. Given the important role of mathematics, the students are required to master mathematics completely in every level of education. Creative thinking requires students to create new ideas in a problem. According to Sumarmo some aspects of cognitive ability to think creatively include the ability to identify problems, generate ideas and diverse original, and examine and assess the relationship between options and alternatives [1]. Students can find a new relationship, expand and update an existing idea. Therefore, learning with the Think-Talk-Write model is expected to enable students to conduct discussions by their respective groups to bring them to find concepts and develop critical and creative thinking outcomes. Khoe states that GeoGebra is an easily used medium, and easy access in search of inspiration makes GeoGebra the right choice in explaining about Geometry [2]. Based on the problems above, it is necessary for teachers to make particular effort to create lessons that improve the ability of student's creative mathematical thinking. This can be done by applying lessons that can facilitate and improve creative thinking students. One of the models that can be used is Think Talk Write assisted by geogebra.

\section{METHODS}

This paper is a literature review, so the method used is summarize and analyze the results of relevant research that has been done. So it provide information that can be used to answer research questions and in accordance with research objectives. Relevant research in this paper relates to improving the ability of students' creative thinking through the Think-Talk-Write model by assisted geogebra.

\section{LITERATURE REVIEW AND DISCUSSION}

In this following section will describe some research relevant to this research. The relevance of his research lies in mathematical critical thinking, students' mathematical creative and research on the Think Talk Write (TTW) model. Euis Istianah conducts research on improving critical thinking and creative math skills using the Eliciting Activities (MEAS) modeling approach [3]. In the results of this study found that the improvement of critical thinking skills of students who received learning with the approach (MEAS) is better than students who received conventional learning, with the category of improvement is classified. Improved critical mathematical and mathematical thinking skills of students who implement learning with approach (MEAS) better than students who received conventional learning. In addition, there is also a positive correlation between critical thinking skills and mathematical creative on learning using the model (MEAS). That is, student's mathematical critical thinking skills and students' mathematical creative thinking skills are better when taught with a model (MEAS) than with conventional learning.

As for some researches that examine about Think Talk Write model that is Indah Indriyani, Ngatman, Joharman entitled Application of Think Talk Write Model (TTW) with media two dimentional figure improving math learning about twodimentional figure character. The results of this study reveal that viewed from the students as a whole, that the application of Think Talk Write Model (TTW) with the media wake up flat can improve the learning of mathematics. In addition, research from Wahyu Hidayat entitled Improving critical thinking skills and mathematical creative high school students through cooperative learning Think Talk Write (TTW) [4]. Based on research conducted by Revelation that improving students' critical and creative 
thinking skills acquiring lessons with Think Talk Write (TTW) is better than students who get learning in the conventional way based on high, moderate, and less than $5 \%$ alpha The research from Widyawati revealed that learning by Think Talk Write (TTW) can improve the critical thinking ability mathematically which is the subject here is the fourth semester students of Mathematics Education Study Program FKIP Ahmad Dahlan University Yogyakarta [5]. The same thing is also said by Imelda that learning with Think Talk Write (TTW) can improve the ability of mathematical creative thinking which is the subject here is SMP Negeri 1 Bandung [6]. Conclusions

Based on the literature above, one of the learning models that can cultivate students' mathematical creative thinking skills is the TTW model introduced by Huinker and Laughin, is basically built through thinking, speaking and writing. The flow of TTW progress begins with the involvement of students in thinking or dialogue with themselves after the reading process, then talking and sharing ideas with friends before writing. Thus, it is expected there is more research related to how much improvement ability of mathematical creative thinking think-talk-write model by assisted geogebra.

\section{ACKNOWLEDGMENT}

This paper supported by my colleagues from Universitas Pendidikan Indonesia who provided insight and expertise in assisted this paper, lecturer, and friends that greatly assisted the paper.

\section{CONCLUSIONS}

Based on the literature above, one of the learning models that can cultivate students' mathematical creative thinking skills is the TTW model introduced by Huinker and Laughin, is basically built through thinking, speaking and writing. The flow of TTW progress begins with the involvement of students in thinking or dialogue with themselves after the reading process, then talking and sharing ideas with friends before writing. Thus, it is expected there is more research related to how much improvement ability of mathematical creative thinking think-talk-write model by assisted geogebra

\section{REFERENCES}

[1] Heris and Utari, "Penilaian Pembelajaran Berbasis Masalah untuk meningkatkan kemampuan berpikir kritis dan komunikatif matematis siswa sekolah dasar," in Nasional edisi khusus, vol. I, pp. 76-89.

[2] Khoe,"Mahir geometri dan matematika dengan geogebra," Jakarta:Andi.

[3] Euis, "Meningkatkan kemampuan berpikir kritis dan kreatif matematika dengan pendekatan model eliciting activities pada siswa SMA," STKIP Siliwangi Bandung, vol. 2, February 2013.

[4] Wahyu, "Meningkatkan kemampuan berpikir kritis dan kreatif matematika siswa SMA melalui pembelajaran kooperatif think-talkwrite," Bandung, STKIP Siliwangi.

[5] Widyawati, "Peningkatan motivasi belajar dan kemampuan berpikir kritis matematis pada mata kuliah aljabar matriks dengan menggunakan model pembelajaran think talk write," Yogyakarta, Universitas Ahmad Dahlan.

[6] Imelda, "Efektivitas penerapan model pembelajaran think-talk-write terhadap peningkatan kemampuan berpikir kreatif siswa," in skripsi, Universitas Pendidikan Indonesia. 